Article

\title{
Germacrone Derivatives as new Insecticidal and Acaricidal Compounds: A Structure-Activity Relationship
}

\author{
Alberto Galisteo Pretel ${ }^{1}$, Helena Pérez del Pulgar ${ }^{1}$, Estela Guerrero de León ${ }^{2}$, \\ José Luis López-Pérez ${ }^{2,3}{ }^{\circledR 0}$, A. Sonia Olmeda ${ }^{4}$, Azucena Gonzalez-Coloma ${ }^{5}{ }^{\circ}$, \\ Alejandro F. Barrero ${ }^{1, *}$ and José Francisco Quílez del Moral ${ }^{1, *}$ (D) \\ 1 Department of Organic Chemistry, Institute of Biotechnology, University of Granada, 18071 Granada, Spain \\ 2 Department of Pharmacology, Faculty of Medicine, University of Panama, Panama 07156, Panama \\ Department of Pharmaceutical Sciences, IBSAL-CIETUS, University of Salamanca, 37007 Salamanca, Spain \\ 4 Faculty of Veterinary, Complutense University of Madrid (UCM), 28040 Madrid, Spain \\ 5 Institute of Agricultural Sciences, CSIC, 28006 Madrid, Spain \\ * Correspondence: afbarre@ugr.es (A.F.B.); jfquilez@ugr.es (J.F.Q.d.M.)
}

Academic Editors: David Díez and María Ángeles Castro

Received: 2 July 2019; Accepted: 2 August 2019; Published: 9 August 2019

check for updates

\begin{abstract}
Currently, the use of synthetic pesticides is the main method of plant protection applied in agri- and horticulture. However, its excessive use leads to the development of pesticide resistance, a contamination of the environment, toxicity to non-target organisms, and risks for human health. With the ultimate aim of contributing to the develop of a more sustainable pest management, we used the natural product germacrone (compound 1), reported to possess significant insecticidal activity, as starting material for the generation of molecular diversity (2-24). Some of the generated derivatives are natural compounds, such as 1,10-epoxygermacrone (2), 4,5-epoxygermacrone (3), gajutsulactone A (7), germacrol (11), isogermacrone (14), 9-hydroxyeudesma-3,7(11)dien-6-one (19), eudesma-4,7(11),dien-8-one (20), eudesma-3,7(11)-dien-8-one (21) and eudesma-4(15),7(11)-dien-8-one (22). Compounds, 7,11-9,10-diepoxigermacr-4,5-en-8-ol (17), 7,11-epoxieudesma-4,7(11)-dien-8-one (23) and 7,11-epoxieudesma-3,7(11)-dien-8-one (24) are described for the first time. The biocidal activity of most of these compounds was assayed against the tick Hyalomma lusitanicum. The acaricidal effects of compound $\mathbf{2 4}$ were four times higher than that of germacrone (1). Compound $\mathbf{2}$ is an insect antifeedant a thousand times more potent than germacrone against Rhopalosiphum padi, which makes this substance a promising selective antifeedant against this cereal pest.
\end{abstract}

Keywords: natural products; organic synthesis; bioactive compounds; insecticidal; ixodicidal

\section{Introduction}

Germacrone (1) is a sesquiterpene isolated in significant amounts from the essential oil of Geranium macrorhyzum (Hungary chemotype) [1]. This essential oil shows antifeedant effects against aphids and ixodicidal activity against the tick Hyalomma lusitanicum along with antifeedant effects against the insect pests Spodoptera littoralis Boisd, Myzus persicae Sulz, and Rhopalosiphum padi, with compound 1 being, to a large extent, responsible for these activities [1]. Additionally, Benelli et al. report both the insecticidal activity of germacrone (1) against mosquito larvae (Culex quinquefasciatus) [2], and also its acaricidal effects against Tetranychus urticae [3].

Regarding the contact toxicity of germacrone against Tribolium castaneum, García et al. report that germacrone results in not being toxic [4], whereas Liang et al. confirm its contact toxicity [5]. The difference in the used concentrations may be argued to rationalize this discrepancy. 
Germacrol (2), the alcohol resulting from the reduction of the carbonyl group of germacrone, results active in choice bioassays against T. castaneum, presenting more activity that germacrone (1) [4]. Germacrone (1) is also used as starting material for the synthesis of 9-methylgermacrene to be used in mosquito control compositions [6].

The significance of the activities reported for germacrone (1) prompted Navarro-Rocha et al. to address the domestication and cultivation of its natural source, G. macrorhyzum (Hungary chemotype), for the sustainable production of this natural product. In this context, and after considering the particular functionality of this molecule $[7,8]$, we selected germacrone as a series lead for the development of both new ixodicidal agents and new aphid antifeedants. Thus, 23 compounds were generated from germacrone (1), mostly after one or two chemical steps, and their biocide activity against the target species was tested and compared to that of germacrone (1).

\section{Results and Discussion}

Germacrone (1) presents an appropriate molecular structure and functionality to be used in a reagent-based approach as a source of chemical diversity. Figure 1 shows some of the transformations planned to be carried out.

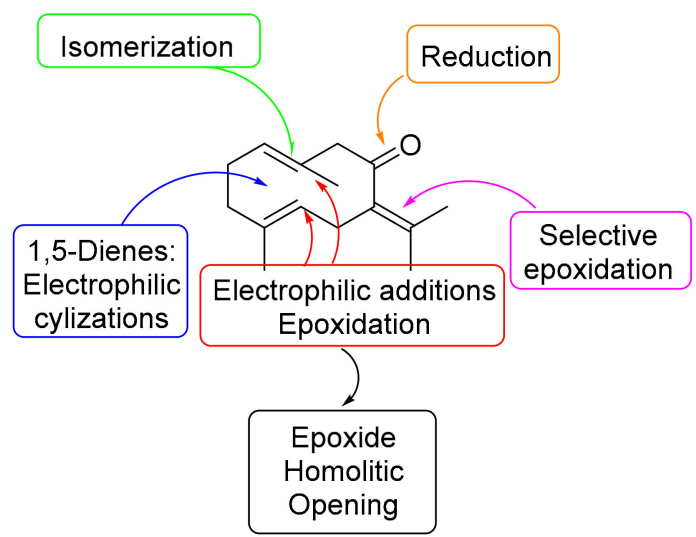

Figure 1. Generation of structural diversity from germacrone (1).

Some of the compounds tested were synthesized following protocols previously reported by some of us, and include only one or two synthetic steps from germacrone (1) [7].

The synthesis of compounds $\mathbf{2 - 1 0}$ are summarized in Scheme 1 . Direct epoxidation of germacrone (1) with mCPBA yields a mixture of epoxides 2-3 in a 4:1 ratio. Epoxides 2 and 3 are also natural products obtained from the rhizomes of several Curcuma species [9-11]. The ionic opening of 1(10)-epoxygermacrone (2) triggered by the Lewis acid $\mathrm{InBr}_{3}$ results in the generation of the spiro-alcohols 4-5 (30\%). Dess-Martin oxidation of 4-5 produces the corresponding ketone 6 with an acceptable yield. Treatment of 4,5-epoxygermacrone (3) with $\mathrm{GaCl}_{3}$ as a Lewis acid causes the opening of 2 to give a natural product known as gajutsulactone A (7) (72\%) [12], together with minor amounts of diketone (8) $(18 \%)$. On the other hand, the treatment of 3 with titanocene monochloride and the subsequent acetylation produces the mixture of acetates 9-10. 


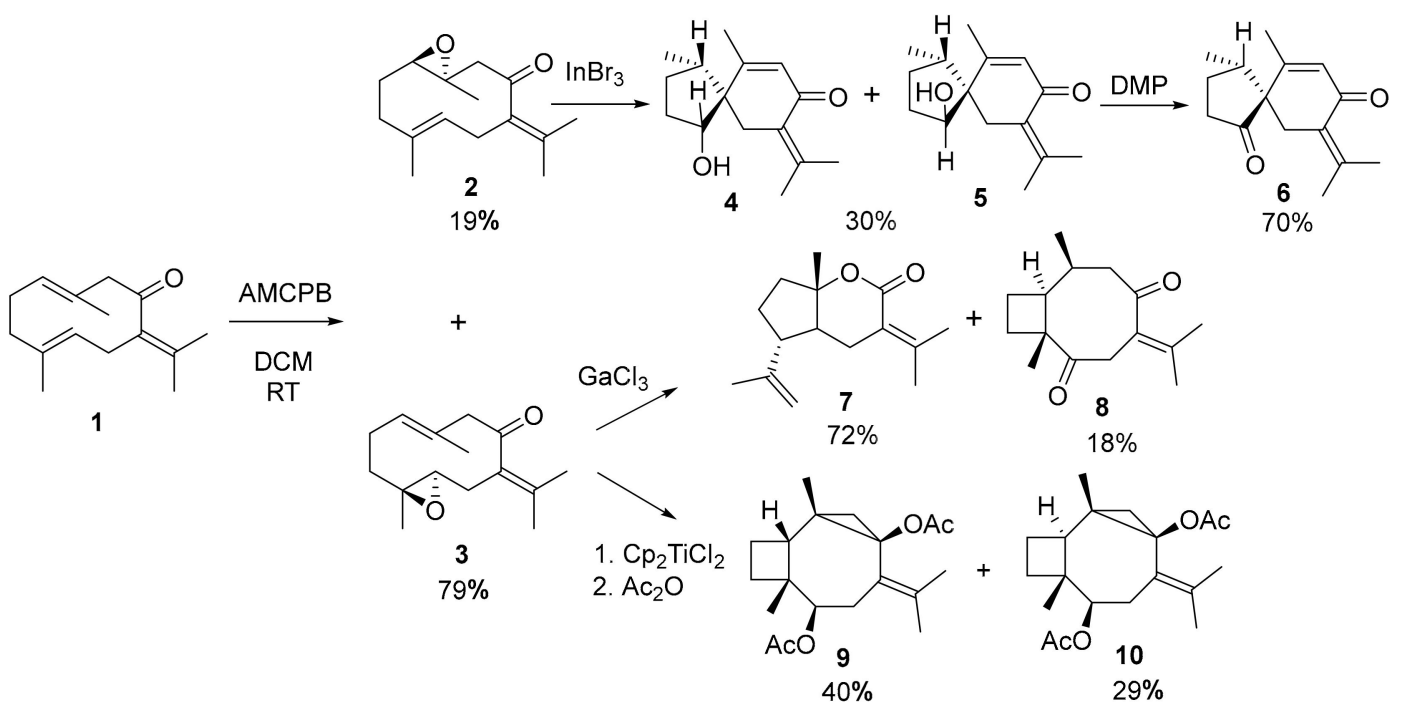

Scheme 1. Synthesis of racemic $\mathbf{2 - 1 0}$ from germacrone (1). Yield of the isolated products is shown.

Attempts to achieve the chemoselective epoxidation of the exocyclic double bond of $\mathbf{1}$ using $\mathrm{H}_{2} \mathrm{O}_{2} / \mathrm{NaOH}$ in different solvents were unsuccessful, since the isomerization of the double bond 1,(10) took place before the start of the epoxidation process. Compound $\mathbf{1 3}$ was then obtained following the protocol described by Enev and Tsankova [13], although varying the vanadium species used for the C7-C11 selective epoxidation of $\mathbf{1 1}$ (Scheme 2).

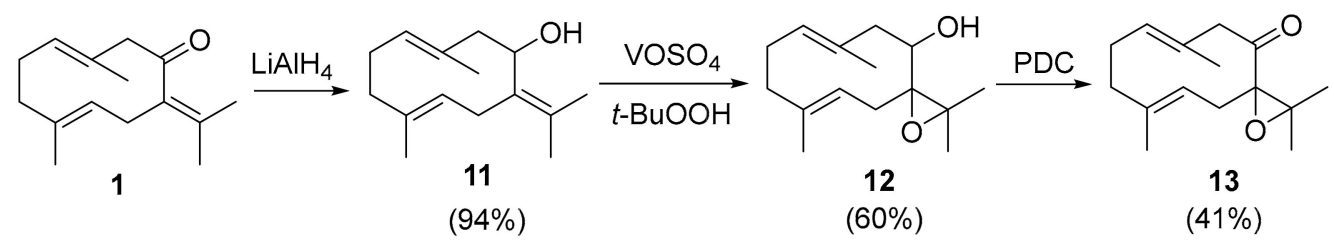

Scheme 2. Synthesis of racemic epoxide 13. Yield of the isolated products is shown.

Epoxide 13 shows in its ${ }^{1} \mathrm{H}-\mathrm{NMR}$ at room temperature three sets of signals that can be attributed to three energetically similar conformers, with relatively high barriers of interconnection between them. The three sets of signals appear better resolved when the NMR spectrum was performed at $-20{ }^{\circ} \mathrm{C}$ (Figure 2, see also Supplementary Material). The ability of the ten-membered ring of the germacradiene species to undergo conformational changes is well known, and has been the subject of multiple computational studies [14-19]. This conformational flexibility plays an important role in their biosynthetic transformation to other sesquiterpene skeletons [20,21], and in the reactivity of these compounds, since the spatial disposition of the different conformers determines the outcome of the corresponding reactions $[22,23]$.

This prompted us to undertake a computational study of compound 13. Initially, a conformational hybrid search method recommended for macrocyclic systems [24] and implemented in Macromodel [25], allowed the detection of 8 conformers for each of the C7 epimers of compound 13, which were subsequently optimized with Gaussian16 [26] using the B3LYP/6-31+G(d,p) $[27,28]$ level of theory. The 8 main conformers found for the $7 S$-epimer are represented in Figure 3 . These conformers are described as up-up (UU), up-down (UD), down-up (DU) and down-down (DD), depending upon the orientation of the C14 and C15 methyl groups, in accordance with the terminology introduced by Watson and Kashyap [19]. 


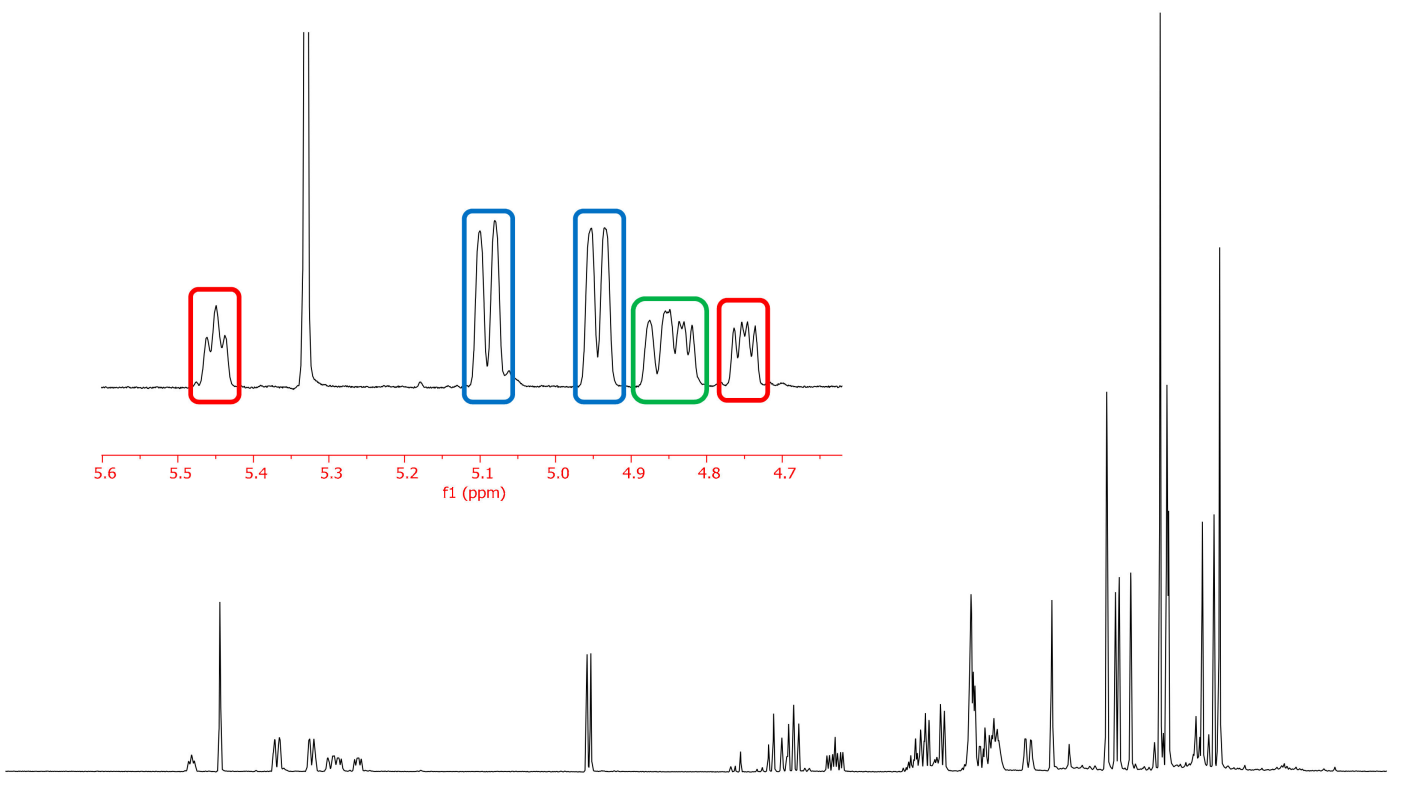

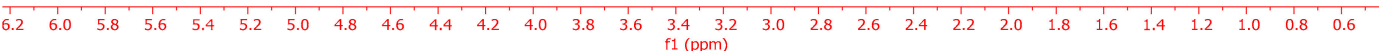

Figure 2. ${ }^{1} \mathrm{H}-\mathrm{NMR}$ spectrum of epoxide 13 at $-20{ }^{\circ} \mathrm{C}$. Grouped in red, blue and green are the three sets of olefinic signals attributable to the three conformers of this molecule existing in solution.
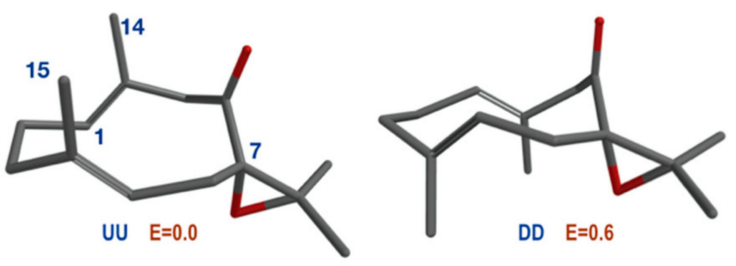

DD $E=0.6$

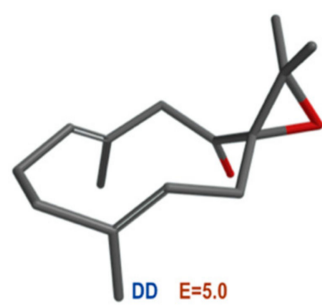

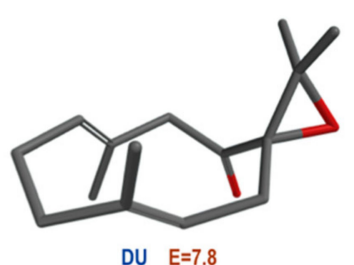

DU $E=7.8$
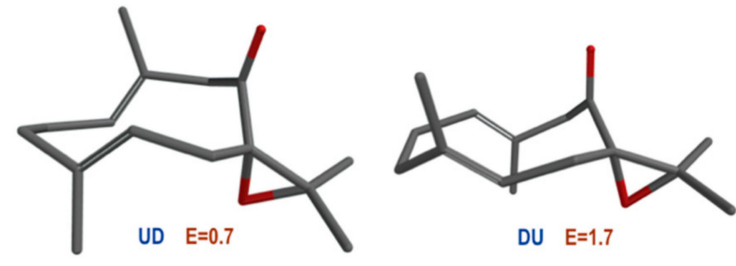

DU $E=1.7$

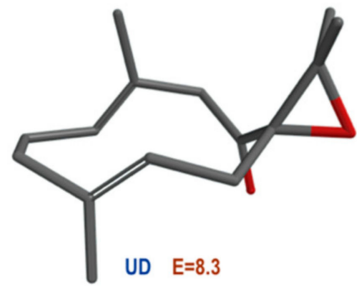

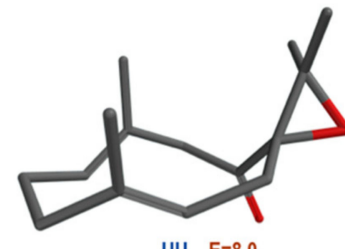

UU $E=8.0$

Figure 3. Main conformers of the 7S-epimer of epoxide 13. Relative free energies (red) to the conformer $\mathrm{UU}$ in $\mathrm{kcal} / \mathrm{mol}(\mathrm{B} 3 \mathrm{LYP}-6-31+\mathrm{G}(\mathrm{d}, \mathrm{p}))$.

The four conformations with the down disposition of ketone at C8 are in-between 5 to $8 \mathrm{kcal} / \mathrm{mol}$ less stable than the global minimum conformer UU with the ketone at C8 also up, so their population contribution in the conformational equilibrium of this compound will be practically null, according to the Boltzman distribution equation. From the four lower energy conforms, DD and UD conformers possess free energy values $0.7-0.8 \mathrm{kcal} / \mathrm{mol}$ higher than the global minimum UU, while the fourth conformer is $1.7 \mathrm{kcal} / \mathrm{mol}$ higher in its free energy value. These data would point to the possibility of the coexistence of different conformations in its structure at room temperature.

In order to justify the observation of three sets of signals in the ${ }^{1} \mathrm{H}-\mathrm{NMR}$ spectrum of epoxide 13, conformational exchange studies were undertaken between the three lowest-energy conformations by rotation around the two planes of both double bonds present in the molecule. These barriers of exchange between the three conformations (Figures 4-6), (although surmountable at room temperature), are 
relatively high (around $16 \mathrm{kcal} / \mathrm{mol}$ ), which would suggest a low rate of exchange between conformers, and therefore a differentiation in the NMR spectrum.

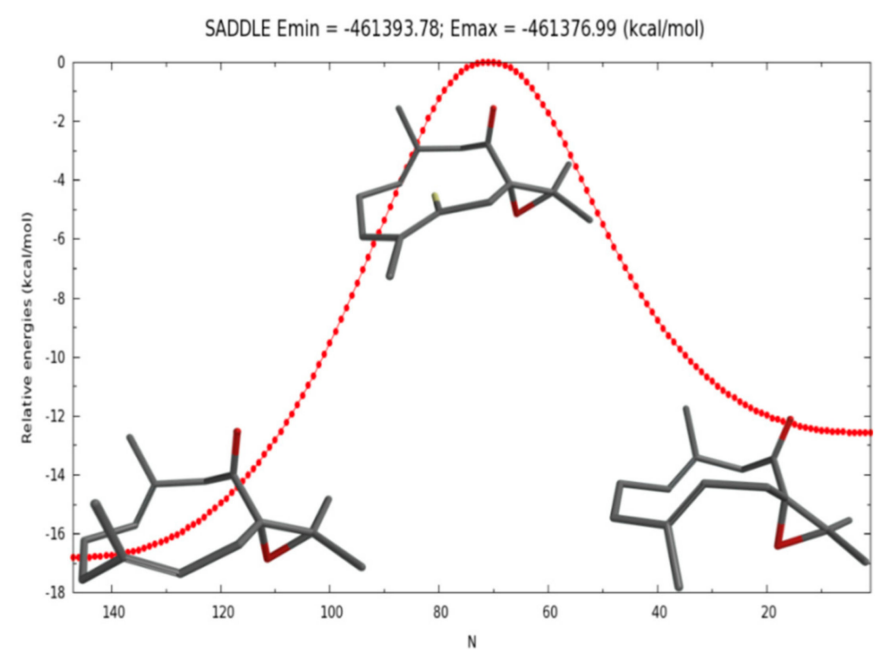

Figure 4. Barrier of exchange between conformations UU and UD and the transition state between both of them.

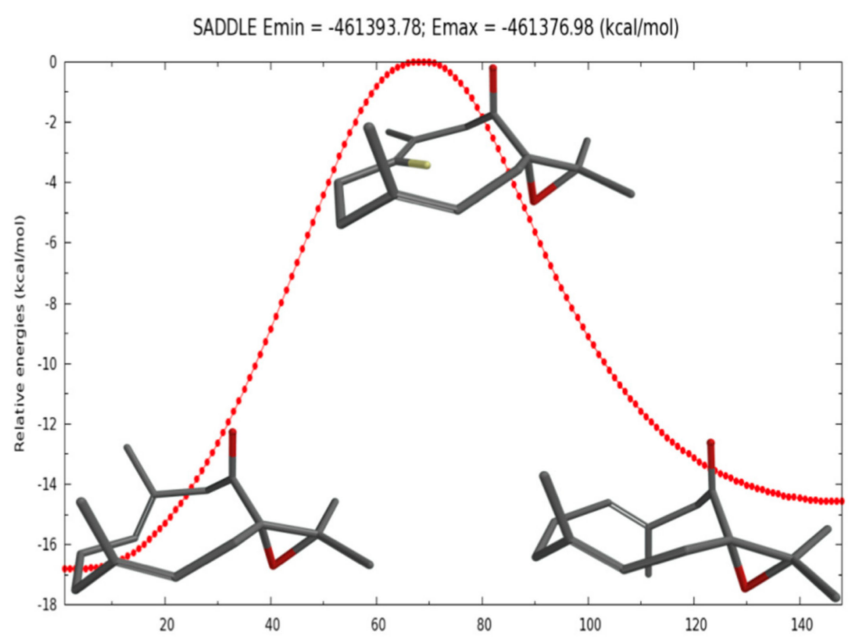

Figure 5. Barrier of exchange between conformations UU and DU and the transition state between both of them.

Finally, the theoretical ${ }^{1} \mathrm{H}-{ }^{1} \mathrm{H}$ nuclear coupling constants $\left(\mathrm{J}_{\mathrm{H}}-\mathrm{H}\right)$ were calculated by applying the scaled proton-proton Bally and Rablen methodology [29] for the three most stable conformers of compound 13. These values were compared with the experimental data measured in dichloromethane at $-10^{\circ} \mathrm{C}$. Gratifyingly, a remarkable coincidence was observed between the theoretical and experimental data (Table 1).

Table 1. Comparison between the theoretical coupling constant for conformer UU (JUU), DD (JDD) and UD (JUD) and the corresponding experimental values (Jexp) measured for compound 13.

\begin{tabular}{ccccccc}
\hline & $J_{\text {UU }}$ & $J_{\operatorname{Exp}}$ & $J_{\text {DD }}$ & $J_{\operatorname{Exp}}$ & $J_{\text {UD }}$ & $J_{\operatorname{Exp}}$ \\
\hline $\mathrm{H}_{1-2 \mathrm{a}}$ & 3.6 & $\mathrm{a}$ & 12.3 & 12.5 & 7.6 & 7.5 \\
$\mathrm{H}_{1-2 \mathrm{~b}}$ & 12.3 & 12.3 & 3.9 & $\mathrm{a}$ & 9.9 & 7.5 \\
$\mathrm{H}_{5-6 \mathrm{a}}$ & 3.6 & $\mathrm{a}$ & 10.0 & 10.7 & 10.4 & 10.4 \\
$\mathrm{H}_{5-6 \mathrm{~b}}$ & 12.1 & 11.9 & 6.7 & 7.0 & 6.3 & 5.9 \\
\hline
\end{tabular}

a The value of these coupling constants could not be measured accurately, although they must be close to $2 \mathrm{~Hz}$. 


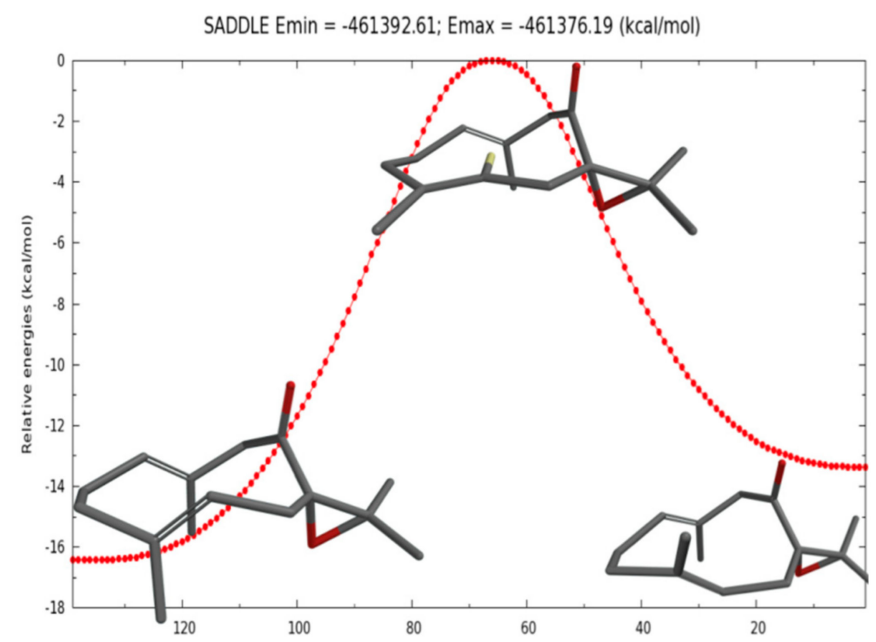

Figure 6. Barrier of exchange between conformations DD and DU and the transition state between both of them.

A final support to both experimental and theoretical data was found after analyzing the NOEDIFF experiments performed in compound 13 (Figure 7). These data also suggests that the DD, UU and UD conformers were the three ones existing in dichloromethane solution for this substance.

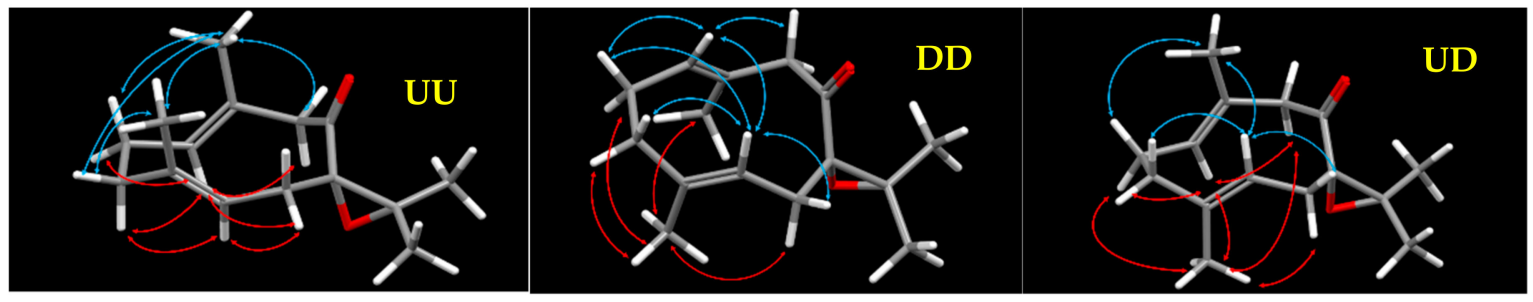

Figure 7. Observed NOEs (indicated by blue and red arrows) for the three conformers of $\mathbf{1 3}$ (UU, DD and UD) existing in solution.

Getting back to the preparation of derivatives of $\mathbf{1}$, isogermacrone (14) was obtained from $\mathbf{1}$ after $\mathrm{NaOEt}-$ mediated isomerization to afford a $86 \%$ yield of the natural product 14 [30]. The chemoselective epoxidation of the conjugated double bond of $\mathbf{1 4}$ employing alkaline $\mathrm{H}_{2} \mathrm{O}_{2}$ in $\mathrm{EtOH}$ affords epoxide $15(20 \%)$ (Scheme 3). Epoxide 15 could be generated more efficiently by direct epoxidation of isogermacrone with $\mathrm{H}_{2} \mathrm{O}_{2}$ in $\mathrm{EtOH}(65 \%)$.

LAH-mediated reduction of isogermacrone (14) yields isogermacrol (16) (54\%). The NMR spectra of this molecule only shows acceptable resolution when performed at high temperature. The lack of resolution at room temperature can be attributed to the existence of coalescence phenomena at this temperature. The epoxydation of isogermacrol (16) was not selective and diepoxide 17 was originated after a vanadium-catalyzed double epoxidation. The treatment of isogermacrone (14) with mCPBA leads selectively to 4,5 -epoxyderivative 18 , which was converted to eudesmanone 19 , via a cyclization process triggered by diethylaluminium chloride [10]. Compound 19 is a natural product isolated from Curcuma phaeocaulis [31].

Finally, epoxyeudesmenes $\mathbf{2 3}$ and $\mathbf{2 4}$ are obtained again in only two steps. The first one involves a Lewis acid-mediated cyclization of germacrone (1) to afford eusdesmadienes $20(15 \%)$ and $21(24 \%)$ and $22(3 \%)$. These three eudesmanes are natural products isolated from different essential oils [32-34]. The epoxydation of $\mathbf{2 0}$ and $\mathbf{2 1}$ with the alkaline peroxide system $\mathrm{H}_{2} \mathrm{O}_{2} / \mathrm{NaOH}$ affords epoxides $\mathbf{2 3}$ and 24 with acceptable yields (Scheme 4). 


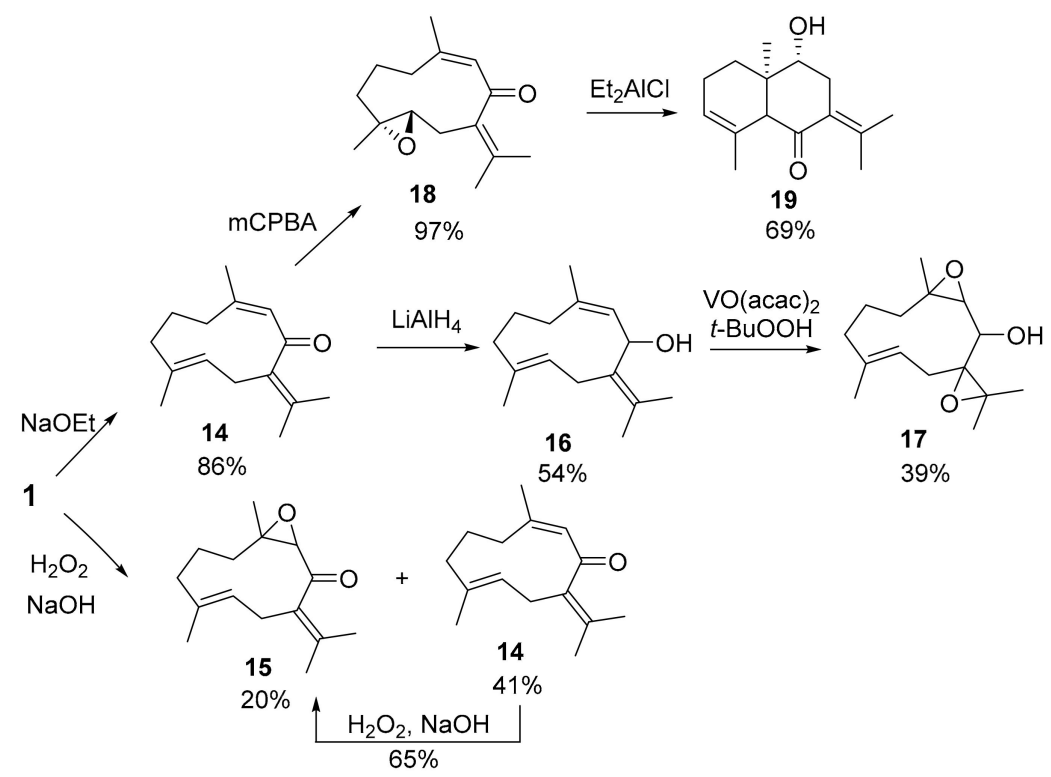

Scheme 3. Synthesis of racemic isogermacrone derivatives. The yield of isolated products is shown.

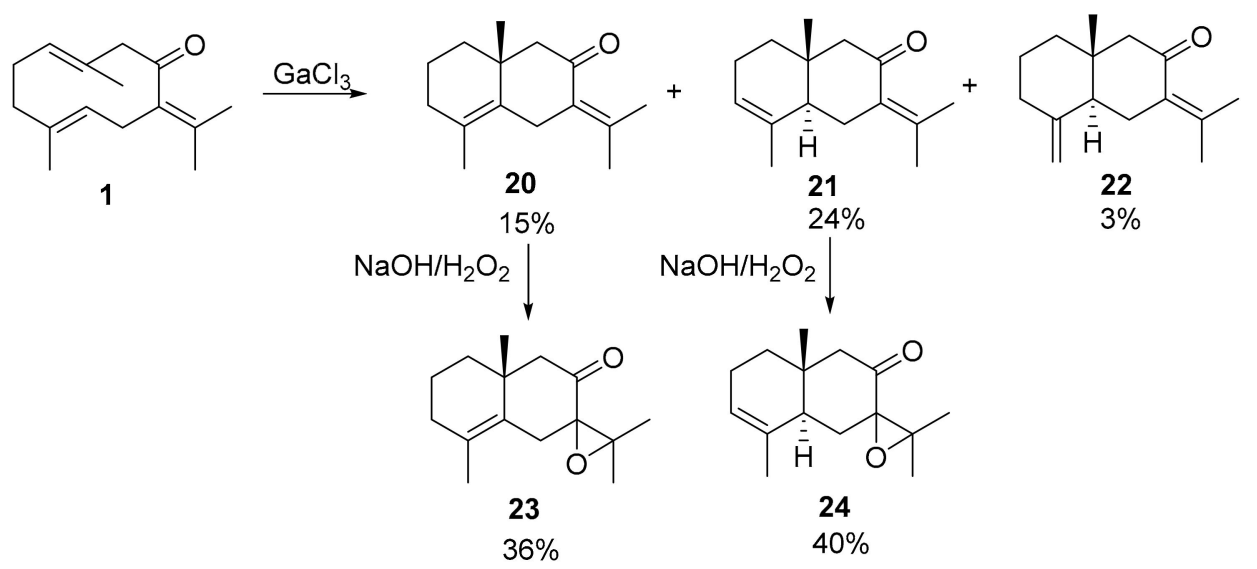

Scheme 4. Synthesis of racemic epoxyeudesmenes 23 and 24 . Yield of isolated products is shown.

At this point, we tested the acaricidal of germacrone (1) and of most of its derivatives against the hard tick H. lusitanicum. The results obtained are shown in Table 2.

The most active ixodicidal compounds result in being epoxyeudesmene 24 and isogermacrone 14, and then, germacrone (1), 7,11-epoxigermacrone (13), and 4,5-epoxigermacrone (3). The bicyclic diketone 8, 1,10-epoxigermacrona (2), 9,10-epoxiisogermacrona (15), lactone 7 (gajutsulactone A) and eudesmane 19 were the less active derivatives. Epoxyeudesmene 24, presenting an $\mathrm{LD}_{50}$ four times higher than that of germacrone (1), may be considered a promising ixodicidal candidate.

From a structure-activity approach, isogermacrone (14) is closely-related to germacrone (1), whereas compounds $\mathbf{1 3}$ and $\mathbf{2 4}$ contain an epoxide close the carbonyl group, instead of a double bond. All this seems to indicate that the presence of an epoxy function located in the $\alpha, \beta$ position to the carbonyl group enhances the ixodicidal activity. Both substances may be considered analogs of the sesquiterpene with eremophilane skeleton ligudicine reported as a strong ixodicidal [35]. On the other hand, the presence of an epoxide at C4-C5 (3) does not affect the activity of these compounds, nor does the existence of a keto group in a cyclooctane ring (8). In these cases, the enone functionality must be responsible for the observed activity. Finally, other structural modifications in $\mathbf{1}$, such as the presence of a lactone instead of the ketone, or the isomerization of the double bond, cause a significant decrease of the activity. Nine molecules (4-6, 9-10 and 17-21) result in being inactive. In this case, the disappearance of the enone (9-10) or the presence of the highly strained spirane system may well 
be the causes of the inactivity. The antifeedant effects of these germacrone derivatives against the insect pest S. littoralis Boisd, M. persicae Sulz, and R. padi L were also tested (Table 3). None of the compounds assayed improve the moderate-high activity of germacrone against $S$. littoralis. Only diketone 8 presents a similar activity, whereas the epoxyderivatives 2 and 3 , the diepoxide $\mathbf{1 7}$ and the acetylated tricycles $\mathbf{9}$ and $\mathbf{1 0}$ result in being less active than germacrone. Similar results were found with M. persicae.

Table 2. Acaricidal activity of germacrone derivatives against a H. lusitanicum Koch.

\begin{tabular}{cccc}
\hline \multirow{2}{*}{ Compound } & \% Mortality $^{\mathbf{a}}$ & \multicolumn{2}{c}{ Effective Lethal Doses $\mathbf{( m g / m L )}$} \\
\cline { 2 - 4 } & $\mathbf{1 0} \mathbf{m g} / \mathbf{m L})$ & $\mathbf{L D}_{\mathbf{5 0}} \mathbf{b}^{\mathbf{b}}$ & $\mathbf{L D}_{\mathbf{9 0}} \mathbf{b}$ \\
\hline $\mathbf{1}$ & $100 \pm 0$ & $1.08(0.7-1.38)$ & $3.13(2.66-3.93)$ \\
$\mathbf{2}$ & $100 \pm 0$ & $2.7(2.43-3.01)$ & $4.1(3.67-4.77)$ \\
$\mathbf{3}$ & $98.3 \pm 1.7$ & $1.47(1.16-1.76)$ & $3.45(2.48-4.22)$ \\
$\mathbf{4}$ & $45.3 \pm 24.9$ & - & - \\
$\mathbf{5}$ & $8.6 \pm 12.1$ & - & - \\
$\mathbf{6}$ & $42.6 \pm 2.5$ & - & - \\
$\mathbf{7}$ & $100 \pm 0$ & $2.44(2.08-2.79)$ & $4.47(3.95-5.27)$ \\
$\mathbf{8}$ & $100 \pm 0$ & $<1.25$ & $<1.25$ \\
$\mathbf{9}$ & - & - & - \\
$\mathbf{1 0}$ & $0 \pm 0$ & - & - \\
$\mathbf{1 1}$ & $24.6 \pm 0.6$ & - & - \\
$\mathbf{1 3}$ & $100 \pm 0$ & $1.21(1.04-1.4)$ & $2.43(2.12-2.89)$ \\
$\mathbf{1 4}$ & $100 \pm 0$ & $0.96(0.88-1.05)$ & $1.39(1.25-1.56)$ \\
$\mathbf{1 5}$ & $100 \pm 0$ & $\sim 2.32$ & $\sim 2.98$ \\
$\mathbf{1 7}$ & $32.1 \pm 17.3$ & - & - \\
$\mathbf{1 9}$ & $0 \pm 0$ & - & - \\
$\mathbf{2 0}$ & 0 & - & - \\
$\mathbf{2 1}$ & 0 & - & - \\
$\mathbf{2 3}$ & $100 \pm 0$ & $4.14(3.85-4.48)$ & $6.33(5.82-7.04)$ \\
$\mathbf{2 4}$ & $91.9 \pm 0.6$ & $0.23(0.12-0.47)$ & $1.91(1.57-2.54)$ \\
Thymol ${ }^{\mathbf{c}}$ & 100 & $0.18(0.16-0.20)$ & $0.27(0.24-0.31)$ \\
\hline
\end{tabular}

a Data corrected according to Schenider Orelli's formula. ${ }^{b}$ Doses needed to give 50 and $90 \%$ mortality (95\% Confidence Limits). ${ }^{\text {c }}$ From Navarro-Rocha et al. [1].

Table 3. Antifeedant effects of germacrone derivatives against S. littoralis, M. persicae and R. padi. Effective doses $\left(\mathrm{EC}_{50} \mathrm{in} \mathrm{mg} / \mathrm{mL}\right.$ ) have been included for the positive controls azadiractin (AZA) and farnesol (FAR).

\begin{tabular}{|c|c|c|c|c|c|c|}
\hline \multirow{2}{*}{ Compound } & \multicolumn{2}{|c|}{ S. littoralis } & \multicolumn{2}{|c|}{ M. persiscae } & \multicolumn{2}{|c|}{ R.padi } \\
\hline & $\%$ FI $^{a}$ & $\mathrm{EC}_{50} \mathrm{~b}$ & $\% \mathrm{SI}^{\mathrm{a}}$ & $\mathrm{EC}_{50} \mathrm{~b}$ & $\% \mathrm{SI}^{\mathrm{a}}$ & $\mathrm{EC}_{50} \mathrm{~b}$ \\
\hline 1 & $98.6 \pm 0.6$ & $1.9(0.1-3.6)$ & $82.2 \pm 5.0$ & $2.8(2.2-3.4)$ & $69.6 \pm 6.5$ & $<5$ \\
\hline 2 & $76.93 \pm 6.7$ & $<5$ & $69.0 \pm 7.8$ & $<5$ & $97.8 \pm 1.0$ & $0.006(0.27-0.2)$ \\
\hline 3 & $69.9 \pm 11.3$ & $<5$ & $64.0 \pm 8.9$ & $<5$ & $94.5 \pm 1.7$ & $0.2(-0.1-0.4)$ \\
\hline 6 & - & - & $60.6 \pm 6.8$ & $<5$ & - & - \\
\hline 7 & $61.1 \pm 11.7$ & $<5$ & $61.6 \pm 9.1$ & $<5$ & $97.3 \pm 1.3$ & $0.02(0.006-0.07)$ \\
\hline 8 & $90.8 \pm 3.3$ & $\sim 2.5$ & $75.6 \pm 7.2$ & $<5$ & $98.3 \pm 1.2$ & $0.8(0.6-1.0)$ \\
\hline 9 & $73.8 \pm 15.4$ & $<5$ & $91.0 \pm 2.6$ & $<5$ & - & - \\
\hline 10 & $78.6 \pm 12.7$ & $<5$ & $88.5 \pm 3.1$ & $<5$ & - & - \\
\hline 11 & $54.3 \pm 8.71$ & - & $45.0 \pm 9.1$ & - & $38.44 \pm 8.8$ & - \\
\hline 13 & $54.6 \pm 9.4$ & - & $66.1 \pm 7.4$ & $<5$ & $92.7 \pm 2.2$ & $2.3(2.1-2.5)$ \\
\hline 14 & $49.8 \pm 11.3$ & - & $71.4 \pm 6.1$ & $<5$ & $84.4 \pm 6.5$ & $<5$ \\
\hline 15 & $54.0 \pm 11.0$ & - & $75.0 \pm 5.1$ & $1.0(0.01-1.4)$ & $69.3 \pm 7.2$ & $3.69(3.3-4.0)$ \\
\hline 17 & $79.7 \pm 7.1$ & $<5$ & $50.4 \pm 9.3$ & - & $86.0 \pm 4.5$ & $1.8(1.4-2.1)$ \\
\hline 23 & $53.9 \pm 9.6$ & - & $55.8 \pm 9.8$ & - & $87.0 \pm 4.5$ & $1.5(1.1-1.9)$ \\
\hline 24 & $33.9 \pm 15.6$ & - & $48.5 \pm 9.2$ & - & $52.5 \pm 8.8$ & - \\
\hline $\mathrm{AZA}^{\mathrm{c}} \mathrm{RY}$ & \multicolumn{2}{|c|}{$0.5 \times 10^{-6}\left(0.2 \times 10^{-8}-0.7 \times 10^{-4}\right)$} & \multicolumn{2}{|l|}{ 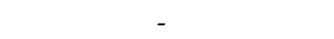 } & \multicolumn{2}{|r|}{-} \\
\hline FAR $^{d}$ & \multicolumn{2}{|c|}{-} & \multicolumn{2}{|c|}{$14.9(12.1-18.3)$} & \multicolumn{2}{|c|}{$1.7(1.2-2.7)$} \\
\hline
\end{tabular}

a \%FI/SI $=(1-(\mathrm{T} / \mathrm{C})) \times 100$, where $\mathrm{T}$ and $\mathrm{C}$ are feeding/settling on treated and control leaf disks at a dose of $5 \mathrm{mg} / \mathrm{mL}$.

${ }^{\mathrm{b}} \mathrm{EC}_{50}$, effective dose $(\mathrm{mg} / \mathrm{mL})$ to give a $50 \%$ inhibition (95\% Confidence Limits). ${ }^{\mathrm{c}}$ From González-Coloma et al.

[36]. ${ }^{d}$ From Santana et al. [37]. 
Thus, only 15 shows activity comparable to that of germacrone. Four compounds, 2, 8, 10 and 13, present low-moderate activity, and the remaining ones were inactive, or show very low activity.

Much more interesting are the results obtained against $R$. padi. Thus, two compounds, 1,10-epoxygermacrone (2) and gajutsulactone $\mathrm{A}(7)$, result in being very active against this aphid $\left(\mathrm{EC}_{50}\right.$ values: $6 \times 10^{-3}$ and $2 \times 10^{-2}$ ). These data convert these two substances into promising selective antifeedants against this cereal pest.

Four other molecules $(3,8,17$ and 23) show high activity. Finally, compounds 13 and 15 present moderate activity, while the remaining compounds show no relevant effect.

\section{Materials and Methods}

\subsection{Instruments and Chemicals}

Silica gel SDS $60(35-70 \mu \mathrm{m})$ was used for flash column chromatography. NMR spectra were acquired with Varian Direct-Drive $600\left({ }^{1} \mathrm{H} 600 \mathrm{MHz} /{ }^{13} \mathrm{C} 150 \mathrm{MHz}\right)$, Varian Direct-Drive $500\left({ }^{1} \mathrm{H}\right.$ $\left.500 \mathrm{MHz} /{ }^{13} \mathrm{C} 125 \mathrm{MHz}\right)$ and Varian Direct-Drive $400\left({ }^{1} \mathrm{H} 400 \mathrm{MHz} /{ }^{13} \mathrm{C} 100 \mathrm{MHz}\right)$. Accurate mass determinations were achieved with a SYNAPT G2-Si Q-TOF mass spectrometer (Waters, Milford, MA, USA) equipped with high-efficiency T-Wave ion mobility and an orthogonal Z-spray ${ }^{\mathrm{TM}}$ electrospray ionization (ESI) source. MassLynx v.4.1 software was used for HRMS instrument control, peak detection, and integration. The reactions were monitored by TLC, which were performed on $0.25-\mathrm{mm}$ E. Merck silica gel plates (60F-254) and involves the use of UV light for visualization and solutions of phosphomolybdic acid in EtOH, and heat as the developing agents. HPLC with UV light and RI detection was also used. The reagents were purchased at the highest quality that was commercially available, and were used without further purification.

\subsection{Synthesis}

Compounds 1-6, 9-10, 14, and 18-19 were prepared as described previously by some of us [7].

\subsubsection{Cyclization of 4,5-epoxygermacrone (3) with $\mathrm{GaCl}_{3}$}

To a solution of 4,5-epoxygermacrone (3) (150mg, $0.64 \mathrm{mmol})$ in dry DCM (10 mL) GaCl $3(11 \mathrm{mg}$, $0.1 \mathrm{mmol}$ ) was added under an argon atmosphere at $-20^{\circ} \mathrm{C}$. This mixture was stirred for $90 \mathrm{~min}$ and monitored by thin-layer chromatography analysis. Upon consumption of the starting material the mixture was evaporated in vacuo. The crude products were purified by flash chromatography (H:MTBE, 7:3) to obtain $108 \mathrm{mg}$ of $\mathbf{7}(72 \%)$ and $27 \mathrm{mg}$ of 8 (18\%). Compounds 7 and 8 were described previously [7].

\subsubsection{Synthesis of 7,11-epoxygermacrone (13)}

To a solution of $\mathbf{1}(1.5 \mathrm{~g}, 6.8 \mathrm{mmol})$ in dry THF $(20 \mathrm{~mL})$ under argon atmosphere was added $200 \mathrm{mg}$ of $\mathrm{LiAlH}_{4}$ at $-10{ }^{\circ} \mathrm{C}$. The reaction mixture was stirred at this temperature for $10 \mathrm{~min}$ and monitored by thin-layer chromatography analysis. Upon consumption of the starting material, $0.15 \mathrm{~mL}$ of water, a solution of $6 \mathrm{~N} \mathrm{NaOH}(0.15 \mathrm{~mL})$ and $0.6 \mathrm{~mL}$ of water were added dropwise. The mixture was filtered over silica gel and $\mathrm{Na}_{2} \mathrm{SO}_{4}(2: 1)$ and washed with MTBE. The reaction was evaporated in vacuo to obtain $1.4 \mathrm{~g}$ of $\mathbf{1 1}(94 \%)$. Spectroscopic data of germacrol (11) were previously described [4].

To a solution of germacrol (11) $(1000 \mathrm{mg}, 4.54 \mathrm{mmol})$ in benzene $(25 \mathrm{~mL})$ under an argon atmosphere was added $37 \mathrm{mg}$ of $\mathrm{VOSO}_{4}(0.23 \mathrm{mmol})$. After the reaction mixture was heated at reflux temperature for $10 \mathrm{~min}, 1.6 \mathrm{~mL}$ of $\mathrm{t}-\mathrm{BuOOH}(9.08 \mathrm{mmol})$ was added. The reaction was then refluxed for 30 additional min and monitored by thin-layer chromatography. Upon consumption of the starting material, the mixture was diluted with $250 \mathrm{~mL}$ of EtOAc, washed with a saturated solution of $\mathrm{NaHCO}_{3}$ $(3 \times 100 \mathrm{~mL})$ and brine $(3 \times 100 \mathrm{~mL})$. The organic layer was dried over $\mathrm{Na}_{2} \mathrm{SO}_{4}$ and evaporated in vacuo. The crude product was purified by flash chromatography (H:MTBE, 9:1) to obtain $616 \mathrm{mg}$ of 7,11-epoxyisogermacrol (12) (60\%). ${ }^{1} \mathrm{H}-\mathrm{NMR}\left(400 \mathrm{MHz}, \mathrm{CDCl}_{3}\right) \delta 4.82(\mathrm{dd}, J=11.8,3.1 \mathrm{~Hz}, 1 \mathrm{H}), 4.51$ 
$(\mathrm{d}, J=11.3 \mathrm{~Hz}, 1 \mathrm{H}), 4.00(\mathrm{~d}, J=10.0 \mathrm{~Hz}, 1 \mathrm{H}), 2.63(\mathrm{dd}, J=14.8,11.3 \mathrm{~Hz}, 1 \mathrm{H}), 2.52(\mathrm{~d}, J=10.1 \mathrm{~Hz}, 1 \mathrm{H})$, $2.44(\mathrm{~d}, J=13.0 \mathrm{~Hz}, 1 \mathrm{H}), 2.34(\mathrm{td}, J=12.3,4.9 \mathrm{~Hz}, 1 \mathrm{H}), 2.29-2.19(\mathrm{~m}, 2 \mathrm{H}), 2.09(\mathrm{dd}, J=12.4,5.0 \mathrm{~Hz}$, $1 \mathrm{H}), 2.00(\mathrm{td}, J=12.1,5.4 \mathrm{~Hz}, 1 \mathrm{H}), 1.60(\mathrm{~s}, 3 \mathrm{H}), 1.55(\mathrm{~d}, 6 \mathrm{H}), 1.46(\mathrm{~s}, 3 \mathrm{H}) .{ }^{13} \mathrm{C}-\mathrm{NMR}\left(100 \mathrm{MHz}, \mathrm{CDCl}_{3}\right)$ $\delta 134.52,133.32,129.78,123.98,72.48,70.46,63.38,46.28,38.73,35.25,25.22,22.25,21.20,16.66,16.39$. HRMS (ESI+) $\mathrm{m} / \mathrm{z}$ calculated for $\mathrm{C}_{15} \mathrm{H}_{24} \mathrm{O}_{2}[\mathrm{M}+\mathrm{H}]^{+} 237.1855$, found 237.1838.

To a solution of $12(160 \mathrm{mg}, 0.68 \mathrm{mmol})$ in dry DMF $(3.5 \mathrm{~mL})$ under an argon atmosphere, 1.8 $\mathrm{g}$ of PDC $(4.78 \mathrm{mmol})$ were added at $0{ }^{\circ} \mathrm{C}$. The reaction mixture was stirred at this temperature for $30 \mathrm{~min}$ and monitored by thin-layer chromatography. Upon consumption of the starting material, the reaction was diluted in $35 \mathrm{~mL}$ of MTBE and washed with $35 \mathrm{~mL}$ of water. The aqueous layer was then washed with MTBE $(3 \times 20 \mathrm{~mL})$. The combined organic layer was washed with brine $(3 \times 20 \mathrm{~mL})$, dried over $\mathrm{Na}_{2} \mathrm{SO}_{4}$ and evaporated in vacuo. The crude product was purified by flash chromatography (H:MTBE, 6:1) to obtain $101 \mathrm{mg}$ of 7,11-epoxygermacrone (13) $(41 \%) .{ }^{1} \mathrm{H}-\mathrm{NMR}\left(500 \mathrm{MHz}, \mathrm{CD}_{2} \mathrm{Cl}_{2}\right.$, $\left.-10^{\circ} \mathrm{C}\right)$. Signals assigned to conformer UU: $\delta 5.09(\mathrm{~d}, J=12.3 \mathrm{~Hz}, 1 \mathrm{H}), 4.95(\mathrm{~d}, J=11.9 \mathrm{~Hz}, 1 \mathrm{H}), 3.8(\mathrm{~d}, J$ $=9,6 \mathrm{~Hz}, 1 \mathrm{H}), 2.92(\mathrm{t}, J=12.8 \mathrm{~Hz}, 1 \mathrm{H}), 2,38(\mathrm{~m}, 1 \mathrm{H}), 2,29(\mathrm{~d}, 9.5 \mathrm{~Hz}, 1 \mathrm{H}), 2.16(\mathrm{~m}, 1 \mathrm{H}), 2.07(\mathrm{~m}, 1 \mathrm{H})$, $1.93(\mathrm{dd}, J=13.9,2.7 \mathrm{~Hz}, 1 \mathrm{H}), 1.6(\mathrm{~s}, 3 \mathrm{H}), 1.35(\mathrm{~s}, 3 \mathrm{H})$. Signals assigned to conformer DD: $\delta 4.87(J=$ $12.5 \mathrm{~Hz}, 1 \mathrm{H}), 4.83(\mathrm{dd}, J=10.7,7.0 \mathrm{~Hz}, 1 \mathrm{H}), 3.02-1.92(\mathrm{~m}, 2 \mathrm{H}), 2.76(\mathrm{dd}, J=14.3,6.1 \mathrm{~Hz}, 1 \mathrm{H}), 2.41(\mathrm{~m}$, $1 \mathrm{H}), 2.17(\mathrm{~m}, 1 \mathrm{H}), 2.12(\mathrm{~m}, 1 \mathrm{H}), 2.07(\mathrm{~m}, 1 \mathrm{H}), 1.82(\mathrm{~s}, 3 \mathrm{H}), 1.56(\mathrm{~s}, 3 \mathrm{H})$. Signals assigned to conformer UD: $\delta 5.45(\mathrm{t}, \mathrm{J}=7.5 \mathrm{~Hz}, 1 \mathrm{H}) 4.74(\mathrm{dd}, J=10.4,5.6 \mathrm{~Hz}, 1 \mathrm{H}), 3.78(\mathrm{~d}, J=9.6 \mathrm{~Hz}, 1 \mathrm{H}), 2.72(\mathrm{dd}, J=13.5$, $5.9 \mathrm{~Hz}, 1 \mathrm{H}), 2.35(\mathrm{~d}, J=9,3 \mathrm{~Hz}, 1 \mathrm{H}), 2.34(\mathrm{~m}, 1 \mathrm{H}), 2.18(\mathrm{~m}, 2 \mathrm{H}), 2.10(\mathrm{~m}, 1 \mathrm{H}), 1.55(\mathrm{~s}, 3 \mathrm{H}), 1.5(\mathrm{~s}, 3 \mathrm{H})$. ${ }^{13} \mathrm{C}-\mathrm{NMR}\left(125 \mathrm{MHz}, \mathrm{CD}_{2} \mathrm{Cl}_{2}\right.$ ). Signals assigned to conformer UU: $\delta 207.5,133.3,122.4,48.2,37.8,27.6$, 23.5, 16.0, 15.3. Signals assigned to conformer DD: $\delta 207.0,132.9,122.9,50.2,28.5,24.5,23.3,19.5,15,7$. Signals assigned to conformer UD: $\delta 206.9,130.7,121.4,49.9,28.7,23.4,15.8,15.6$. HRMS (ESI+) $\mathrm{m} / \mathrm{z}$ calculated for $\mathrm{C}_{15} \mathrm{H}_{22} \mathrm{O}_{2}[\mathrm{M}+\mathrm{H}]^{+} 235.1698$, found 235.1685.

\subsubsection{Synthesis of 9,10-epoxyisogermacrone (15)}

To a solution of 1 ( $200 \mathrm{mg}, 0.92 \mathrm{mmol})$ in $\mathrm{EtOH}(5 \mathrm{~mL})$ was added $0.5 \mathrm{~mL}$ of $\mathrm{H}_{2} \mathrm{O}_{2}(30 \%)$ and $0.5 \mathrm{~mL}$ of a solution of $5 \mathrm{~N} \mathrm{NaOH}$ dropwise. The reaction mixture was stirred for 40 days at room temperature and monitored by thin-layer chromatography analysis. Upon consumption of the starting material, the mixture was diluted with $75 \mathrm{~mL}$ of MTBE, washed with brine $(3 \times 20 \mathrm{~mL})$, dried over $\mathrm{Na}_{2} \mathrm{SO}_{4}$ and evaporated in vacuo. The crude product was purified by flash chromatography (H:MTBE, 9:1) to obtain $90 \mathrm{mg}$ of $\mathbf{1 4}(41 \%)$ and $64 \mathrm{mg}$ of $\mathbf{1 5}(20 \%) .{ }^{1} \mathrm{H}-\mathrm{NMR}\left(500 \mathrm{MHz}, \mathrm{DMSO}-d_{6}, 85^{\circ} \mathrm{C}\right) \delta 5.17$ $(\mathrm{dd}, J=9.1,6.5,1 \mathrm{H}), 3.59(\mathrm{~s}, 1 \mathrm{H}), 2.98(\mathrm{dd}, J=15.1,6.5 \mathrm{~Hz}, 1 \mathrm{H}), 2.90-2.85(\mathrm{~m}, 1 \mathrm{H}), 2.16-2.11(\mathrm{ddd}, J$ $=13.6,8.6,6.1 \mathrm{~Hz}, 1 \mathrm{H}), 1.98(\mathrm{dt}, J=12.9,6.0 \mathrm{~Hz}, 1 \mathrm{H}), 1.74(\mathrm{~s}, 3 \mathrm{H}), 1.71-1.70(\mathrm{~m}, 1 \mathrm{H}), 1.68(\mathrm{bs}, 3 \mathrm{H})$, $1.68-1.66(\mathrm{~m}, 1 \mathrm{H}), 1.47(\mathrm{~s}, 3 \mathrm{H}), 1.38(\mathrm{~s}, 3 \mathrm{H}), 1.24-1.20(\mathrm{~m}, 1 \mathrm{H}) .{ }^{13} \mathrm{C}-\mathrm{NMR}\left(125 \mathrm{MHz}\right.$, DMSO- $\left.d_{6}, 85{ }^{\circ} \mathrm{C}\right) \delta$ 204.98, 136.74, 135.68, 130.70, 123.17, 67.99, 65.33, 37.59, 28.30, 27.44, 22.11, 21.72, 21.52, 19.97, 15.24. HRMS (ESI+) $m / z$ calculated to $\mathrm{C}_{15} \mathrm{H}_{23} \mathrm{O}_{2}[\mathrm{M}+\mathrm{H}]^{+} 235.1698$, found 235.1696 .

To a solution of $\mathbf{1 4}(100 \mathrm{mg}, 0.46 \mathrm{mmol})$ in $2.5 \mathrm{~mL}$ of EtOH) was added $0.25 \mathrm{~mL}$ of $\mathrm{H}_{2} \mathrm{O}_{2}(30 \%)$ and $0.25 \mathrm{~mL}$ of a solution of $5 \mathrm{~N} \mathrm{NaOH}$ dropwise. The reaction mixture was stirred for $48 \mathrm{~h}$ at room temperature, and then diluted with $40 \mathrm{~mL}$ of MTBE, washed with brine $(3 \times 10 \mathrm{~mL})$, dried over $\mathrm{Na}_{2} \mathrm{SO}_{4}$ and evaporated in vacuo. The crude product was purified by flash chromatography (H:MTBE, 4:1) to obtain $70 \mathrm{mg}$ of $\mathbf{1 5}(65 \%)$.

\subsubsection{Synthesis of 7,11-9,10-diepoxygermacr-4,5-en-8-ol (17)}

To a solution of $\mathbf{1 4}(419 \mathrm{mg}, 1.9 \mathrm{mmol})$ in dry THF (23 mL) under argon atmosphere, was added $108 \mathrm{mg}$ of $\mathrm{LiAlH}_{4}$ at $-10{ }^{\circ} \mathrm{C}$. The reaction mixture was stirred at this temperature for $100 \mathrm{~min}$ and monitored by thin-layer chromatography. Upon consumption of the starting material the reaction mixture was diluted with MTBE, and then, $1 \mathrm{~mL}$ of water, $1 \mathrm{~mL}$ of $6 \mathrm{~N} \mathrm{NaOH}$ and $3 \mathrm{~mL}$ of water were added dropwise. Then the reaction was filtered over silica gel and $\mathrm{Na}_{2} \mathrm{SO}_{4}(2: 1)$ and washed with EtOAc. The solvent was evaporated in vacuo. The crude product was purified by flash chromatography (H:MTBE, 4:1) to obtain $227 \mathrm{mg}$ of isogermacrol (16) (54\%). ${ }^{1} \mathrm{H}-\mathrm{NMR}\left(600 \mathrm{MHz}\right.$, DMSO- $\left.d_{6}, 80{ }^{\circ} \mathrm{C}\right) \delta$ 
$5.26(\mathrm{~d}, J=9.7 \mathrm{~Hz}, 1 \mathrm{H}), 4.97(\mathrm{bs}, 1 \mathrm{H}), 4.75(\mathrm{~d}, J=9.6 \mathrm{~Hz}, 1 \mathrm{H}), 2.94(\mathrm{dd}, J=14.5,5.2 \mathrm{~Hz}, 1 \mathrm{H}), 2.65(\mathrm{t}, J=$ $12.3 \mathrm{~Hz}, 1 \mathrm{H}), 2.37(\mathrm{ddd}, J=14.1,9.9,4.4 \mathrm{~Hz}, 1 \mathrm{H}), 2.07-1.98(\mathrm{dp}, J=26.4,6.5 \mathrm{~Hz}, 2 \mathrm{H}), 1.87(\mathrm{~d}, J=2.1 \mathrm{~Hz}$, $3 \mathrm{H}), 1.83-1.77(\mathrm{~m}, 1 \mathrm{H}), 1.64(\mathrm{~s}, 3 \mathrm{H}), 1.62(\mathrm{~s}, 3 \mathrm{H}), 1.60-1.57(\mathrm{~m}, 2 \mathrm{H}), 1.50(\mathrm{~s}, 3 \mathrm{H}) .{ }^{13} \mathrm{C}-\mathrm{NMR}(125 \mathrm{MHz}$, DMSO- $\left.d_{6}, 80^{\circ} \mathrm{C}\right): \delta 132.4,128.5,72.6,43.5,41.3,34.4,31.5,25.6,24.6,24.5,22.5,18.0$. HRMS (ESI+) $\mathrm{m} / \mathrm{z}$ calculated to $\mathrm{C}_{15} \mathrm{H}_{25} \mathrm{O}[\mathrm{M}+\mathrm{H}]^{+} 221.1905$, found 221.1897.

To a solution of $16(227 \mathrm{mg}, 1.04 \mathrm{mmol})$ in dry benzene $(10 \mathrm{~mL})$ under argon atmosphere, was added $14 \mathrm{mg}$ of $\mathrm{VO}(\mathrm{acac})_{2}$. The reaction mixture was stirred for $10 \mathrm{~min}$ at refluxing temperature. Then, $0.37 \mathrm{~mL}$ of $\mathrm{t}-\mathrm{BuOOH}(3.2 \mathrm{mmol})$ was added. The reaction was stirred for $30 \mathrm{~min}$ at reflux temperature, and monitored by thin-layer chromatography. Upon consumption of the starting material, the mixture was diluted with $180 \mathrm{~mL}$ of EtOAc, washed with a saturated solution of $\mathrm{NaHCO}_{3}(3 \times 50 \mathrm{~mL})$, brine $(3 \times 50 \mathrm{~mL})$, dried over $\mathrm{Na}_{2} \mathrm{SO}_{4}$ and evaporated in vacuo. The crude product was purified by flash chromatography (H:MTBE, 3:2) to obtain $100 \mathrm{mg}$ of 7,11-9,10-diepoxigermacr-4,5-en-8-ol (17) (39\%). ${ }^{1} \mathrm{H}-\mathrm{NMR}\left(500 \mathrm{MHz}, \mathrm{CDCl}_{3}\right): \delta 4.97(\mathrm{~d}, J=12.4 \mathrm{~Hz}, 1 \mathrm{H}), 3.56(\mathrm{~d}, J=9.2 \mathrm{~Hz}, 1 \mathrm{H}), 2.80(\mathrm{dd}, J=9.2,0.9 \mathrm{~Hz}$, $1 \mathrm{H}), 2.61(\mathrm{dd}, J=13.9,12.5 \mathrm{~Hz}, 1 \mathrm{H}), 2.50(\mathrm{~s}, 1 \mathrm{H}), 2.26-2.12(\mathrm{~m}, 3 \mathrm{H}), 1.91-1.74(\mathrm{~m}, 3 \mathrm{H}), 1.67(\mathrm{~s}, 3 \mathrm{H})$, $1.65(\mathrm{~s}, 3 \mathrm{H}), 1.48(\mathrm{~s}, 3 \mathrm{H}), 1.37(\mathrm{~s}, 3 \mathrm{H}), 1.32-1.26(\mathrm{~m}, 1 \mathrm{H}) .{ }^{13} \mathrm{C}-\mathrm{NMR}\left(125 \mathrm{MHz}, \mathrm{CDCl}_{3}\right): \delta 138.22,119.77$, $69.42,67.03,66.89,63.28,62.48,36.81,31.86,27.91,22.29,22.03,21.95,21.44,15.29$. HRMS (ESI+) $\mathrm{m} / \mathrm{z}$ calculated to $\mathrm{C}_{15} \mathrm{H}_{25} \mathrm{O}_{3}[\mathrm{M}+\mathrm{H}]^{+} 253.1804$, found 253.1794.

\subsubsection{Cyclization of germacrone (1) with $\mathrm{GaCl}_{3}$}

To a solution of $1(150 \mathrm{mg}, 0.69 \mathrm{mmol})$ in dry DCM $(7 \mathrm{~mL})$ under argon atmosphere, $12 \mathrm{mg}$ of $\mathrm{GaCl}_{3}(0.069 \mathrm{mmol})$ were added. The reaction mixture was stirred for $40 \mathrm{~min}$ at room temperature and monitored by thing layer chromatography. Upon consumption of the starting material the reaction was evaporated in vacuo. The crude product was purified by flash chromatography (H:MTBE, 95:5) to obtain $22 \mathrm{mg}$ of eudesma-4,7(11)-dien-8-one (20) (15\%), $37 \mathrm{mg}$ of eudesma-3,7(11)-dien-8-one (21) (24\%) and $4 \mathrm{mg}$ of eudesma-4(15),7(11)-dien-8-one (22) (3\%). Compounds 20 and 21 were previously described by some of us [7].

\subsubsection{Epoxidation of eudesma-4,7(11)-dien-8-one (20) with $\mathrm{NaOH}$ and $\mathrm{H}_{2} \mathrm{O}_{2}$}

To a solution of $20(298 \mathrm{mg}, 1.37 \mathrm{mmol})$ in $\mathrm{MeOH}(45 \mathrm{~mL})$, was added $1 \mathrm{~mL}$ of $2 \mathrm{~N} \mathrm{NaOH}$ and 2.7 $\mathrm{mL}$ of $\mathrm{H}_{2} \mathrm{O}_{2}\left(30 \%\right.$ in water) at $0{ }^{\circ} \mathrm{C}$. The reaction mixture was stirred at this temperature for $22 \mathrm{~h}$ and monitored by thin-layer chromatography. Upon consuming of the starting material, the mixture was diluted with $155 \mathrm{~mL}$ of MTBE, washed with brine $(3 \times 50 \mathrm{~mL})$, dried over $\mathrm{Na}_{2} \mathrm{SO}_{4}$ and evaporated in vacuo. The crude product was purified by flash chromatography (H:MTBE, 4:1) to obtain $137 \mathrm{mg}$ of 7,11-epoxyeudesma-4,7(11)-dien-8-one (23) (36\%). ${ }^{1} \mathrm{H}-\mathrm{NMR}\left(500 \mathrm{MHz}, \mathrm{CDCl}_{3}\right): \delta 2.77(\mathrm{~d}, J=17.3 \mathrm{~Hz}$, $1 \mathrm{H}), 2.68(\mathrm{~d}, J=17.3 \mathrm{~Hz}, 1 \mathrm{H}), 2.37(\mathrm{~s}, 2 \mathrm{H}), 2.04-1.95(\mathrm{~m}, 2 \mathrm{H}), 1.79-1.61(\mathrm{~m}, 2 \mathrm{H}), 1.59(\mathrm{~s}, 3 \mathrm{H}), 1.56-1.48$ $(\mathrm{m}, 1 \mathrm{H}), 1.43(\mathrm{~s}, 3 \mathrm{H}), 1.42-1.36(\mathrm{~m}, 1 \mathrm{H}), 1.31(\mathrm{~s}, 3 \mathrm{H}), 1.14(\mathrm{~s}, 3 \mathrm{H}) .{ }^{13} \mathrm{C}-\mathrm{NMR}\left(125 \mathrm{MHz}, \mathrm{CDCl}_{3}\right): \delta 208.00$, $128.77,128.52,68.32,65.64,53.78,37.83,35.01,31.65,29.81,26.54,20.12,19.32,19.17,18.63$. HRMS (ESI+) $\mathrm{m} / \mathrm{z}$ calculated to $\mathrm{C}_{15} \mathrm{H}_{23} \mathrm{O}_{2}[\mathrm{M}+\mathrm{H}]^{+} 235.1698$, found 235.1687 .

\subsubsection{Epoxidation of eudesma-3,7(11)-dien-8-one (21) with $\mathrm{NaOH}$ and $\mathrm{H}_{2} \mathrm{O}_{2}$}

To a solution of $21(98 \mathrm{mg}, 0.45 \mathrm{mmol})$ in $\mathrm{MeOH}(15 \mathrm{~mL})$, was added $0.5 \mathrm{~mL}$ of $2 \mathrm{~N} \mathrm{NaOH}$ solution and $0.8 \mathrm{~mL}$ of $\mathrm{H}_{2} \mathrm{O}_{2}\left(30 \%\right.$ in water) at a temperature of $0{ }^{\circ} \mathrm{C}$. The reaction mixture was stirred at that temperature for $22 \mathrm{~h}$ and monitored by thin-layer chromatography analysis. Upon consumption of the starting material, the mixture was then diluted in $60 \mathrm{~mL}$ of MTBE, washed with brine $(3 \times 20 \mathrm{~mL})$, dried over $\mathrm{Na}_{2} \mathrm{SO}_{4}$ and evaporated in vacuo. The crude product was purified by flash chromatography (H:MTBE, 4:1) to obtain $42 \mathrm{mg}$ of 7,11-epoxyeudesma-3,7(11)-dien-8-one (24)(40\%). ${ }^{1} \mathrm{H}-\mathrm{NMR}(500 \mathrm{MHz}$, $\left.\mathrm{CDCl}_{3}\right): \delta 5.43(\mathrm{bs}, 1 \mathrm{H}) 2.40-2.31(\mathrm{~m}, 2 \mathrm{H}), 2.20(\mathrm{~d}, J=17.7 \mathrm{~Hz}, 1 \mathrm{H}), 2.11(\mathrm{~d}, J=6.0 \mathrm{~Hz}, 1 \mathrm{H}), 2.09-2.01(\mathrm{~m}$, 2H), 1.96-1.90 (m, 1H), $1.63(\mathrm{~s}, 3 \mathrm{H}), 1.53-1.50(\mathrm{~m}, 1 \mathrm{H}), 1.46-1.42(\mathrm{~m}, 1 \mathrm{H}), 1.41(\mathrm{~s}, 3 \mathrm{H}), 1.27(\mathrm{~s}, 3 \mathrm{H}), 0.99$ (s, 3H). ${ }^{13} \mathrm{C}-\mathrm{NMR}\left(126 \mathrm{MHz}, \mathrm{CDCl}_{3}\right): \delta 208.20,133.15,122.26,68.15,65.19,54.62,43.23,37.01,33.63$, 
29.48, 22.46, 21.13, 20.68, 19.61, 18.62. HRMS (ESI+) $m / z$ calculated para $\mathrm{C}_{15} \mathrm{H}_{23} \mathrm{O}_{2}[\mathrm{M}+\mathrm{H}]^{+} 235.1698$, found 235.1697 .

\subsection{Computational Analysis}

A conformational search with Molecular Mechanics (MMFF94) was carried out with the Macromodel Package [25]. Geometry optimizations and energy calculations were performed with Gaussian 16 [26] using DFT [38-40] at the B3LYP/6-31+G(d,p) [27,28] level of theory. Frequency calculations (at $298.15 \mathrm{~K}$ ) at the same level of theory were used to confirm the nature of all stationary points. Transition states were identified by the presence of a single imaginary frequency. To verify that the TSs correspond to the expected interchange between conformers, intrinsic reaction coordinate (IRC) [41-43] calculations were performed at the same level, B3LYP/6-31+G(d,p). The reported energies are expressed in $\mathrm{kcal} / \mathrm{mol}$ and correspond to relative free energies, while those that appear in the IRC plot, expressed also in $\mathrm{kcal} / \mathrm{mol}$, correspond to relative electronic energies, and do not include zero-point energy corrections.

For computation of ${ }^{1} \mathrm{H}-{ }^{1} \mathrm{H}$ coupling constants, we have applied the scaled proton-proton recommendations by Bally $\mathrm{T}$ and Rablen $[(\mathrm{B} 3 \mathrm{LYP} / 6-31 \mathrm{G}(\mathrm{d}, \mathrm{p}) / / \mathrm{B} 3 \mathrm{LYP} / \mathrm{b} 31 y \mathrm{p} / 6-31 \mathrm{~g}(\mathrm{~d})]$, through a multiplication of the calculated Fermi contact terms by 0.9155 [29].

\subsection{Biological Evaluation}

S. littoralis, M. persicae and R. padi colonies were reared on artificial diet [44], bell pepper (Capsicum annuum) and barley (Hordeum vulgare) plants, respectively. The plants are grown from seeds in pots with commercial substrate. The plants for rearing aphids are infected regularly (bell pepper plants with 4 leaves, barley plants of $10 \mathrm{~cm}$ length). The insect colonies and host plants were maintained at 22 $\pm 1{ }^{\circ} \mathrm{C},>70 \%$ relative humidity with a photoperiod of $16: 8 \mathrm{~h}(\mathrm{~L}: \mathrm{D})$ in a growth chamber.

\subsubsection{Antifeedant Activity}

The upper surface of $C$. anuum and $H$. vulgare leaf disks or fragments $\left(1.0 \mathrm{~cm}^{2}\right)$ were treated with $10 \mu \mathrm{L}$ of the test substance. The crude extracts and products were tested at an initial dose of 100 or $50 \mu \mathrm{g} / \mathrm{cm}^{2}$, respectively. Five Petri dishes $(9 \mathrm{~cm}$ diameter) or twenty ventilated plastic boxes $(2 \times$ $2 \mathrm{~cm})$ with two newly molted $S$. littoral is L6 larvae $(<24 \mathrm{~h})$ or ten apterous aphid adults $(24-48 \mathrm{~h}$ old), each were allowed to feed at room temperature for $S$. littoralis $(<2 \mathrm{~h})$, or in a growth chamber for the aphids ( $24 \mathrm{~h}$, environmental conditions as above). Each experiment was repeated 2-3 times (SE $<10 \%$ ) and terminated when the consumption of the control disks reached $65-75 \%$ for S. littoralis, or after $24 \mathrm{~h}$ for the aphids. The leaf disk area consumed was measured on their digitalized images (Image J, http://imagej.nih.gov/ij). Settling was measured by counting the number of aphids settled on each leaf fragment. Feeding or settling inhibition (\%FI or \%SI) was calculated as $\% \mathrm{FI} / \% \mathrm{SI}=[1$ $-(\mathrm{T} / \mathrm{C}) \times 100$ ], where $\mathrm{T}$ and $\mathrm{C}$ are the consumption/settling of the treated and control leaf disks, respectively. The antifeedant effects (\% FI/SI) were analyzed for significance by the nonparametric Wilcoxon signed-rank test.

Extracts and compounds with an FI/SI $>75 \%$ were further tested in a dose-response experiment (3-4 serial dilutions) to calculate their relative potency $\left(\mathrm{EC}_{50}\right.$, the effective dose to give a $50 \%$ feeding/settling reduction) from linear regression analysis (\% FI/SI on Log-dose) [45].

\subsubsection{Ixodicidal Activity}

H. lusitanicum-engorged female ticks were collected in central Spain (Finca La Garganta, Ciudad Real) from their host (deer) and maintained at $22-24{ }^{\circ} \mathrm{C}$ and $70 \% \mathrm{RH}$ until oviposition and egg hatch. Resulting larvae (4-6 weeks old) were used for the bioassays [35]. Briefly, $50 \mu \mathrm{L}$ of test solution were added to $25 \mathrm{mg}$ of powdered cellulose at different concentrations, and the solvent was evaporated. For each test, three replicates with 20 larvae each were used. Dead ticks were counted after $24 \mathrm{~h}$ of contact with the treated cellulose at the environmental conditions described, using a binocular 
magnifying glass. The larvicidal activity data are presented as percent mortality corrected according to Schneider-Orelli's formula. Effective lethal doses $\left(\mathrm{LC}_{50}\right.$ and $\left.\mathrm{LC}_{90}\right)$ were calculated by Probit Analysis (5 serial dilutions, STATGRAPHICS Centurion XVI, version 16.1.02).

\section{Conclusions}

Starting from the natural product germacrone (1), available from cultivated G. macrorrhizum, we have synthesized up to 23 derivatives in 1-3 steps by achieving different cyclizations and by varying the oxidation state of germacrone (1). Some of the synthesized substances are natural products. With these derivatives, we performed ixodicidal tests against $H$. lusitanicum, and antifeedant tests against $S$. littoralis, M. persicae, and R. padi. The most relevant results were obtained with the epoxyeudesmene 24, with four times higher ixodicidal activity than germacrone (1). Additionally, 1,10-epoxygermacrone (2) is one thousand times a more potent antifeedant than germacrone (1) against $R$. padi, therefore indicating that this molecule is a promising selective antifeedant against this cereal pest.

Supplementary Materials: The supplementary material related to this article includes NMR spectra of new compounds is available online.

Author Contributions: A.F.B., A.G.-C. and J.F.Q.d.M. conceived and designed the experiments; J.L.L.-P. and E.G.d.L. performed the theoretical studies; A.G.P. and H.P.d.P. realized the synthetic work; A.G.-C. and A.S.O. carried out the biological assays; A.F.B., A.G.-C., J.L.L.-P. and J.F.Q.d.M. analyzed the data and wrote the paper.

Funding: This research was funded by Grant CTQ-2015-64049-C3-3-R/CTQ2015-64049-C3-1-R; MINISTERIO DE ECONOMÍA Y COMPETITIVIDAD, Spain (MINECO/FEDER).

Conflicts of Interest: The authors declare no conflict of interest.

\section{References}

1. Navarro-Rocha, J.; Barrero, A.F.; Burillo, J.; Olmeda, A.S.; González-Coloma, A. Valorization of essential oils from two populations (wild and commercial) of Geranium macrorrhizum L. Ind. Crops Prod. 2018, 116, 41-45. [CrossRef]

2. Benelli, G.; Pavela, R.; Iannarelli, R.; Petrelli, R.; Cappellacci, L.; Cianfaglione, K.; Afshar, F.H.; Nicoletti, M.; Canale, A.; Maggi, F. Synergized mixtures of Apiaceae essential oils and related plant-borne compounds: Larvicidal effectiveness on the filariasis vector Culex quinquefasciatus Say. Ind. Crops Prod. 2017, 96, 186-195. [CrossRef]

3. Benelli, G.; Pavela, R.; Canale, A.; Nicoletti, M.; Petrelli, R.; Cappellacci, L.; Galassi, R.; Maggi, F. Isofuranodiene and germacrone from Smyrnium olusatrum essential oil as acaricides and oviposition inhibitors against Tetranychus urticae: Impact of chemical stabilization of isofuranodiene by interaction with silver triflate. J. Pest Sci. 2017, 90, 693-699. [CrossRef]

4. García, M.; Donadel, O.J.; Ardanaz, C.E.; Tonn, C.E.; Sosa, M.E. Toxic and repellent effects of Baccharis salicifolia essential oil on Tribolium castaneum. Pest Manag. Sci. 2005, 61, 612-618. [CrossRef] [PubMed]

5. Liang, J.Y.; Liu, X.T.; Gu, J.; Liu, Y.; Ma, X.Y.; Lv, N.; Guo, S.S.; Wang, J.L.; Du, S.S.; Zhang, J. Chemical constituents and insecticidal activity of the essential oils extracted from Artemisia giraldii and Artemisia rubripes against two stored product insects. Med. Chem. 2016, 6, 396/1-396/5. [CrossRef]

6. Hamilton, J.G.C.; Krishnakumari, B. Mistura racêmica, composto, uso de uma mistura racêmica ou de seu isômero constituinte, métodos de controle ou monitoração de mosquitos-pólvora, de prevenção de infecção e de sintetização de ( \pm )-9-metilgermacreno, e, coleira de animal. BR PI0500799 (A) 2016. Available online: https://worldwide.espacenet.com/publicationDetails/biblio?DB=EPODOC\&II=0\&ND= $3 \&$ adjacent $=$ true $\&$ locale $=$ en_EP \&FT $=$ D\&date $=20060912 \& C C=B R \& N R=P I 0500799 A \& K C=A($ accessed on 8 August 2019).

7. Pérez Morales, M.C.; Catalán, J.V.; Domingo, V.; Jaraíz, M.; Herrador, M.M.; Quílez del Moral, J.F.; López-Pérez, J.-L.; Barrero, A.F. Structural diversity from the transannular cyclizations of natural germacrone and epoxy derivatives: A theoretical-experimental study. Chem. Eur. J. 2013, 19, 6598-6612. [CrossRef] [PubMed]

8. Catalán, J.V. Síntesis de terpenoides bioactivos usando sintones terpénicos y ciclaciones mediadas por Ti(III). Ph.D. Dissertation, University of Granada, Granada, Spain, 20 December 2007. 
9. Ulubelen, A.; Gören, N.; Jakupovic, J. Germacrane derivatives from the fruits of Smyrnium creticum. Phytochemistry 1986, 26, 312-313. [CrossRef]

10. Radulović, N.S.; Zlatković, D.; Dekić, M.; Stojanović-Radić, Z. Further antibacterial geranium macrorrhizum 1. metabolites and synthesis of epoxygermacrones. Chem. Biodivers. 2014, 11, 542-550. [CrossRef] [PubMed]

11. Yoshihara, M.; Shibuya, H.; Kitano, E.; Yanagi, K.; Kitagawa, I. The absolute stereostructure of (4s, 5s)-(+)-germacrone 4,5-epoxide from Zedoariae Rhizoma cultivated in Yakushima Island. Chem. Pharm. Bull. 1984, 32, 2059-2062. [CrossRef]

12. Matsuda, H.; Morikawa, T.; Toguchida, I.; Ninomiya, K.; Yoshikawa, M. Medicinal Foodstuffs. XXVIII. Inhibitors of nitric oxide production and new sesquiterpenes, zedoarofuran, 4-epicurcumenol, neocurcumenol, gajutsulactones A and B, and zedoarolides A and B, from Zedoariae Rhizoma. Chem. Pharm. Bull. 2001, 49, 1558-1566. [CrossRef]

13. St. Enev, V.; Tsankova, E.T. Lewis acid catalysed rearrangement of 7,11-epoxyisogermacrone. Formation of a new carbon skeleton. Tetrahedron 1991, 47, 6399-6406. [CrossRef]

14. Maggio, A.M.; Barone, G.; Bruno, M.; Duca, D.; Rosselli, S. Conformational analysis and DFT calculations of $8 \alpha$-hydroxy-germacradiene-6,12-olide derivatives. J. Phys. Org. Chem. 2005, 18, 1116-1122. [CrossRef]

15. Jimeno, M.L.; del Carmen Apreda-Rojas, M.; Cano, F.H.; Rodríguez, B. NMR and x-ray conformational study of artemisiifolin and three other related germacranolides. Magn. Reson. Chem. 2004, 42, 474-483. [CrossRef] [PubMed]

16. Milosavljević, S.; Juranić, I.; Aljančić, I.; Vajs, V.; Todorović, N. Conformational analysis of three germacranolides by the PM3 semi-empirical method. J. Serb. Chem. Soc. 2003, 68, 281-289. [CrossRef]

17. Wong, H.-F.; Brown, G.D. Germacranolides from Artemisia myriantha and their conformation. Phytochemistry 2002, 59, 529-536. [CrossRef]

18. Kulyyasov, A.T.; Bagryanskaya, I.Y.; Gatilov, Y.V.; Shakirov, M.M.; Raldugin, V.A.; Adekenov, S.M.; Seitembetov, T.S. Crystal and molecular structure of subchrysine (3-o-acetylridentine), a new germacranolide from Artemisia subchrysolepis. Russ. Chem. Bull. 1998, 47, 1390-1394. [CrossRef]

19. Watson, W.H.; Kashyap, R.P. Conformations of germacra-1(10),4-dien-6,12-olides and -8,12-olides. A comparison of x-ray diffraction, NMR, and molecular mechanics derived conformations. J. Org. Chem. 1986, 51, 2521-2524. [CrossRef]

20. Minnaard, A.J.; Wijnberg, J.B.P.A.; de Groot, A. The synthesis of germacrane sesquiterpenes and related compounds. Tetrahedron 1999, 55, 2115-2146. [CrossRef]

21. Barquera-Lozada, J.E.; Cuevas, G. Biogenesis of sesquiterpene lactones pseudoguaianolides from germacranolides: Theoretical study on the reaction mechanism of terminal biogenesis of 8-epiconfertin. J. Org. Chem. 2009, 74, 874-883. [CrossRef]

22. Marco, J.A.; Sanz-Cervera, J.F.; García-Lliso, V.; Domingo, L.R.; Carda, M.; Rodríguez, S.; López-Ortiz, F.; Lex, J. Influence of conformational factors on acid-catalyzed cyclizations of germacranolides. Molecular structure of the cyclization products of gallicin and $8 \alpha$-hydroxygallicin (Shonachalin A). Liebigs Ann. 1995, 1837-1841. [CrossRef]

23. Tashkhodzhaev, B.; Abduazimov, B.K. Stereochemistry of sesquiterpenes of the germacrane type. Chem. Nat. Compd. 1997, 33, 382-388. [CrossRef]

24. Kolossváry, I.; Guida, W.C. Low Mode Search. An efficient, automated computational method for conformational analysis: Application to cyclic and acyclic alkanes and cyclic peptides. J. Am. Chem. Soc. 1996, 118, 5011-5019. [CrossRef]

25. Mohamadi, F.; Richards, N.G.J.; Guida, W.C.; Liskamp, R.; Lipton, M.; Caufield, C.; Chang, G.; Hendrickson, T.; Still, W.C. Macromodel—an integrated software system for modeling organic and bioorganic molecules using molecular mechanics. J. Comput. Chem. 1990, 11, 440-467. [CrossRef]

26. Frisch, M.J.; Trucks, G.W.; Schlegel, H.B.; Scuseria, G.E.; Robb, M.A.; Cheeseman, J.R.; Scalmani, G.; Barone, V.; Petersson, G.A.; Nakatsuji, H.; et al. Gaussian 16 Rev. B.01 2016. Available online: https: //gaussian.com/gaussian16/ (accessed on 5 August 2019).

27. Becke, A.D. A new mixing of Hartree-Fock and local density-functional theories. J. Chem. Phys. 1993, 98, 1372-1377. [CrossRef]

28. Becke, A.D. Density-functional thermochemistry. III. The role of exact exchange. J. Chem. Phys. 1993, 98, 5648-5652. [CrossRef] 
29. Bally, T.; Rablen, P.R. Quantum-chemical simulation of ${ }^{1} \mathrm{H}-\mathrm{NMR}$ spectra. 2. Comparison of DFT-based procedures for computing proton-proton coupling constants in organic molecules. J. Org. Chem. 2011, 76, 4818-4830. [CrossRef] [PubMed]

30. Bozhkova, N.V.; Stoev, G.; Orahovats, A.S.; Rizov, N.A. Sesquiterpene ketones from Geranium macrorrhizum. Phytochemistry 1984, 23, 917-918. [CrossRef]

31. Liu, Y.; Ma, J.; Wang, Y.; Donkor, P.O.; Li, Q.; Gao, S.; Hou, Y.; Xu, Y.; Cui, J.; Ding, L.; et al. Eudesmane-type sesquiterpenes from Curcuma phaeocaulis and their inhibitory activities on nitric oxide production in RAW 264.7 Cells. European, J. Org. Chem. 2014, 2014, 5540-5548. [CrossRef]

32. Coll, J.C.; Bowden, B.F.; Tapiolas, D.M.; Willis, R.H.; Djura, P.; Streamer, M.; Trott, L. Studies of australian soft corals-XXXV: The terpenoid chemistry of soft corals and its implications. Tetrahedron 1985, 41, 1085-1092. [CrossRef]

33. Nazaruk, J.; Kalemba, D.; Nazaruk, J.; Kalemba, D. Chemical composition of the essential oils from the roots of Erigeron acris L. and Erigeron annuus (L.) Pers. Molecules 2009, 14, 2458-2465. [CrossRef]

34. Endo, K.; Taguchi, T.; Taguchi, F.; Hikino, H.; Yamahara, J.; Fujimura, H. Antiinflammatory principles of atractylodes Rhizomes. Chem. Pharm. Bull. 1979, 27, 2954-2958. [CrossRef] [PubMed]

35. Ruiz-Vásquez, L.; Olmeda, A.S.; Zúñiga, G.; Villarroel, L.; Echeverri, L.F.; González-Coloma, A.; Reina, M. Insect antifeedant and ixodicidal compounds from Senecio adenotrichius. Chem. Biodivers. 2017, 14, e1600155. [CrossRef] [PubMed]

36. González-Coloma, A.; Gutiérrez, C.; Hübner, H.; Achenbach, H.; Terrero, D.; Fraga, B.M. Selective insect antifeedant and toxic action of ryanoid diterpenes. J. Agric. Food Chem. 1999, 47, 4419-4424. [CrossRef] [PubMed]

37. Santana, O.; Reina, M.; Fraga, B.M.; Sanz, J.; González-Coloma, A. Insect antifeedant fatty acid esters and phytosterols from Echium wildpretii. Chem. Biodiv. 2012, 9, 567-576.

38. Lynch, B.J.; Zhao, Y.; Truhlar, D.G. Effectiveness of diffuse basis functions for calculating relative energies by density functional theory. J. Phys. Chem. A 2003, 107, 1384-1388. [CrossRef]

39. Koch, W.; Holthausen, M.C. A Chemist's Guide to Density Functional Theory, 2nd ed.; Wiley-VCH: Weinheim, Germany, 2000.

40. Parr, R.G.; Yang, W. Density Functional Theory of Atoms and Molecules; Claredon Press: Oxford, UK, 1989.

41. Hratchian, H.P.; Schlegel, H.B. Using Hessian updating to increase the efficiency of a Hessian based predictor-corrector reaction path following method. J. Chem. Theory Comput. 2005, 1, 61-69. [CrossRef] [PubMed]

42. Hratchian, H.P.; Schlegel, H.B. Accurate reaction paths using a Hessian based predictor-corrector integrator. J. Chem. Phys. 2004, 120, 9918-9924. [CrossRef]

43. Gonzalez, C.; Schlegel, H.B. Improved algorithms for reaction path following: Higher-order implicit algorithms. J. Chem. Phys. 1991, 95, 5853-5860. [CrossRef]

44. Poitout, S.; Bues, S. Elevage de plusieurs espèces de lépidotéres Noctundiae sur milieu artificiel riche et sur milieu artificiel simplifiè. Ann. Zool. Ecol. Anim. 1970, 2, 79-91.

45. Burgueño-Tapia, E.; Castillo, L.; González-Coloma, A.; Joseph-Nathan, P. Antifeedant and phytotoxic activity of the sesquiterpene $p$-benzoquinone perezone and some of its derivatives. J. Chem. Ecol. 2008, 34, 766-771. [CrossRef]

Sample Availability: Samples of the compounds are not available from the authors. 